\title{
Pemarkah Frasa Aspektualitas Bahasa Melayu Dialek Sambas
}

\author{
Haries Pribady ${ }^{1)}$ \\ Program Studi Pendidikan Bahasa dan Sastra Indonesia STKIP Singkawang \\ Email: hariespribady@yahoo.com
}

\begin{abstract}
Abstrak. Linguistik tidak sekadar membahas bahasa secara internal, melainkan juga hal-hal yang berada di luar bahasa, termasuk waktu, situasi, dan pengguna bahasa. Pada awalnya dipahami bahwa setiap kata bersifat otonom, bisa berdiri sendiri dan dimaknai hanya dengan merujuk kata yang digunakan. Namun kenyataan yang terjadi tidaklah demikian. Penggunaan kata, khususnya verba, selalu berkaitan dengan hal lain yang berada di luar bahasa. Hal ini mencakup kapan suatu verba digunakan dan bagaimana suatu verba bisa berubah (secara morfologis) karena diakibatkan proses-proses yang menyertai atau berada dalam kegiatan berbahasa. Dalam hal ini, istilah semantik verba perlu diberikan perhatian secara serius karena setiap makna yang timbul akibat penggunaan kata kerja (verba) tidak bisa lepas dari aspek-aspek luar bahasa (ekstralinguistik). Sumarlam (2004: ix) menyebutkan bahwa aspektualitas merupakan unsur semestaan bahasa. Istilah ini diambil sebagai 'common thought' yang mencakup aksionalitas dan aspek [7]. Aspektualitas merupakan gejala ekstralinguistik yang mencakup unsur waktu (time, temporal, moment) dan unsur situasi (state, event, process, dan activity). Bagi beberapa kalangan pengguna bahasa, konsep waktu bisa dipahami dengan konfigurasi antara struktur aspektualitas dan temporalitas yang lazim berlaku di masyarakat Makalah ini membahas pengungkapan penanda waktu internal situasi (aspektualitas) dalam cerita daerah Melayu Sambas.Tujuan penulisan makalah ini adalah untuk memaparkan dan mengungkap penggunaan pemarkah aspektualitas dalam tulisan-tulisan yang ada di cerita daerah. Pengungkapan ini diilakukan dengan sudut pandang sintaksis melalui aspek frasa. Metode yang digunakan adalah deskriptif dengan bentuk penelitian kualitatif.
\end{abstract}

Kata kunci: Aspektualitas, Waktu, Cerita Daerah

\section{PENDAHULUAN}

Ilmu bahasa atau linguistik tidak sekadar membahas bahasa secara internal, melainkan juga hal-hal yang berada di luar bahasa, termasuk waktu, situasi, dan pengguna bahasa. Pada awalnya dipahami bahwa setiap bahasa bersifat otonom, bisa berdiri sendiri dan dimaknai hanya dengan merujuk kata yang digunakan. Namun kenyataan yang terjadi tidaklah demikian. Penggunaan kata, khususnya verba, selalu berkaitan dengan hal lain yang berada di luar bahasa. Hal ini mencakup kapan suatu verba digunakan dan bagaimana suatu verba bisa berubah (secara morfologis) karena diakibatkan proses-proses yang menyertai atau berada dalam kegiatan berbahasa. Dalam hal ini, istilah semantik verba perlu diberikan perhatian secara serius karena setiap makna yang timbul akibat penggunaan kata kerja (verba) tidak bisa lepas dari aspek-aspek luar bahasa (ekstralinguistik).

Berkaitan dengan pembahasan terhadap verba, terdapat tiga subkategori tatabahasa yang berkaitan dengan aspek semantiknya, di antaranya adalah aspektualitas, temporalitas, dan modalitas. Aspektualitas dan temporalitas mempelajari sifat-sifat keberlangsungan situasi (yaitu gejala luar bahasa yang berupa peristiwa, proses/ aktivitas, keadaan) dilihat dari segi waktu yang menyertai keberlangsungan situasi tersebut. Di sisi lain, modalitas mengkaji situasi dari sudut pandang bermacam-macam sikap pembicara terhadap situasi yang berlangsung[8]. Ketiga subkategori tersebut menunjukkan proses morfologis yang luas dan perlu dipahami secara komprehensif agar bisa diklasifikasikan dengan tepat secara gramatikal.

Aspektualitas merupakan gejala yang terdapat dalam setiap bahasa. Hal ini mengacu pada pendapat Sumarlam (2004: ix) yang menyebutkan bahwa aspektualitas merupakan unsur semestaan bahasa. Istilah aspektualitas diambil sebagai common thought yang mencakup aksionalitas dan aspek. Aspektualitas merupakan gejala ekstralinguistik yang mencakup unsur waktu (time, temporal, moment) dan unsur situasi (state, event, process, dan activity). Bagi beberapa kalangan pengguna bahasa, konsep waktu bisa dipahami dengan konfigurasi antara struktur aspektualitas dan temporalitas yang lazim berlaku di masyarakat.

Rencana penelitian yang berfokus pada kajian aspektualitas ini akan melengkapi dan memperluas kajian linguistik pada bahasa-bahasa di nusantara. Fokus-fokus analisis ditekankan pada pengungkapan makna aspektualitas secara sintaksis. Pengungkapan ini dilakukan pada tahap frasa, klausa, dan kalimat majemuk. Tahap klausa dianggap sama dengan kalimat tunggal, sebab cuma memiliki satu konstruksi predikatif: satu konstruksi predikatif mampu menggambarkan situasi yang terdapat dalam kalimat.

Setiap penelitian membutuhkan rujukan berupa teori dan penelitian lain yang relevan. Teori digunakan untuk memudahkan proses analisis, sebagai alat yang digunakan untuk membedah fokus penelitian sedangkan penelitian 
relevan sebagai petunjuk pelaksanaan atau teknis penelitian, kelebihan dan kekurangan penelitian yang telah dilakukan, serta hasil yang diperoleh dari penelitian sebelumnya. Beberapa penelitian sebelumnya yang relevan dengan rencana penelitian ini di antaranya:

1. Nanda Dwi Astri (2014) dalam jurnal yang berjudul Aspektualitas dalam Bahasa Jawa di Desa Bandar Tengah Kecamatan Bandar Khalipah membahas perilaku aspektualitas bahasa Jawa. Penelitian ini menggunakan metode simak libat cakap dan teknik catat dalam pengumpulan datanya. Pada pengkajian data digunakan metode agih dengan teknik lanjutan berupa teknik ganti, teknik balik, dan teknik lesap. Hasil penelitian ini adalah ditemukannya dua belas aspektualiser (pengungkap aspektualitas) yaitu uwes (sudah;telah;selesai), urung (belum), arek (terusmenerus), ijek (masih), entes (baru), tetep (tetap), lekas (mulai), terus-terusan (terus-menerus), sedilut (sebentar;sejenak), kerep (selalu), biosone (biasanya), dan ujug-ujug (tiba-tiba).

2. Mohammad Tadjuddin (2005) pada disertasinya yang berjudul Bahasa Rusia dan Perbandingannya dengan Bahasa Indonesia mengungkapkan aspek morfologi bahasa yang dibatasi pada sufiks $-i$ dan reduplikasi serta aspek sintaksis yang dibatasi pada tataran frasa. Tataran klausa dan kalimat tidak dibahasa dalam penelitian ini.

3. Sumarlam (2001) pada disertasinya yang berjudul Aspektualitas dalam Bahasa Jawa mengungkapkan semua segi morfologis (semua afiks dan reduplikasi) dan semua aspek sintaksis (frasa, klausa, kalimat tunggal, dan kalimat majemuk). Penelitian yang dilakukan Sumarlam menggunakan pendekatan sintaksis kontekstual, yakni pendekatan yang memandang bahwa verba bukan unsur otonom. Verba bersama unsur lain membangun suatu makna aspektualitas tertentu dalam kalimat.

Berdasar beberapa kajian relevan yang telah dikemukakan, rencana penelitian ini akan membahas aspektualitas Bahasa Melayu Dialek Sambas dengan kajian sintaksis. Pemilihan BMDS sebagai objek bertujuan untuk melengkapi korpus penelitian bahasa melayu pesisir yang digunakan di sepanjang pantai utara Kalimantan Barat. Kajian sintaksis dijadikan fokus utama karena aspektualitas berkaitan erat dengan sisi gramatikal dan tentu saja sintaksis (meliputi frasa) sangat memengaruhi sisi gramatikal suatu bahasa.

Berdasarkan latar belakang dan kajian relevan yang telah dipaparkan, masalah yang akan dibahas adalah bagaimanakah cara pengungkapan makna aspektualitas BMDS pada tataran frasa.Tujuan dirumuskan agar proses penelitian bisa dilaksanakan dengan tepat. Tujuan penelitian merupakan hal teknis, berupa perwujudan masalah yang telah ditetapkan. Penentuan tujuan akan membantu penulis meneliti secara sistematis, mengkaji penelitian relevan dengan tepat, mengumpulkan teori dengan tepat, dan menganalisis data dengan tepat, sehingga hasil yang diharapkan bisa tercapai.

\section{METODE}

Penelitian ini akan dilakukan dalam bentuk kualitatif. Penelitian kualitatif adalah penelitian yang bermaksud untuk memahami fenomena tentang apa yang dialami oleh subjek penelitian, misalnya perilaku, persepsi, motivasi, dan lainlain secara holistik, dan dengan cara deskripsi dalam bentuk kata-kata dan bahasa, pada suatu konteks khusus yang alamiah dan dengan memanfaatkan berbagai metode ilmiah [4]. Pendapat tersebut dipertegas oleh Bogdan dan Taylor dalam [4] yang mengemukakan bahwa penelitian kualitatif menghasilkan data deskriptif berupa kata-kata tertulis atau lisan orang-orang dan perilaku yang dapat diamati. Data tersebut berasal dari naskah wawancara, catatan lapangan, video tape, dokumen pribadi, catatan, dan dokumen resmi lainya. Oleh karena itu, dalam penelitian kualitatif, data yang dianalisis dan diuraikan dalam bentuk kata-kata atau kalimat berdasarkan data di lapangan.

Metode deskriptif digunakan dalam penelitian ini, yakni penelitian yang berusaha mendeskripsikan suatu gejala, peristiwa, kejadian yang terjadi saat sekarang. Penelitian yang bersifat deskriptif dilakukan pada data yang terurai dalam bentuk kata-kata, bukan dalam bentuk angka. Penelitian deskriptif memusatkan perhatian kepada masalahmasalah aktual sebagaimana adanya pada saat penelitian berlangsung. Nawawi menjelaskan bahwa metode deskriptif dapat diartikan sebagai prosedur pemecahan masalah yang diselidiki dengan menggambarkan atau melukiskan keadaan subjek atau objek penelitian (seseorang, lembaga, masyarakat, dan lain-lain: dalam hal ini adalah bahasa) pada saat sekarang berdasarkan fakta-fakta yang tampak atau sebagaimana adanya [6]. Melalui penelitian deskriptif, peneliti berusaha mendeskripsikan peristiwa dan kejadian yang menjadi pusat perhatian tanpa memberikan perlakukan khusus terhadap peristiwa tersebut. Variabel yang diteliti bisa tunggal (satu variabel) bisa juga lebih dan satu variabel.

\section{Data dan Sumber Data}

a. Data

Data yang digunakan dalam penelitian ini adalah frasa dalam cerita-cerita rakyat yang mengandung atau mampu mengungkapkan aspektualitas. Dengan bantuan teks, data bisa dianalisis sesuai dengan masalah penelitian yang telah dikemukakan. Dengan memerhatikan penggunaan verba, peneliti akan menganalisis pengungkapan makna aspektualitas pada tataran frasa, klausa, dan kalimat majemuk yang terdapat di dalam teks.

\section{b. Sumber Data}

Data yang bersumber dari manusia, dokumen, buku, dan sebagainya yang digunakan dalam penelitian disebut dengan sumber data. Dalam penelitian ini penulis membatasi sumber data hanya pada dokumen tertulis cerita rakyat Melayu yang telah ditranskripsi. Pemilihan dokumen tertulis didasari oleh sifatnya yang mantap dan terencana serta memiliki tingkat interferensi yang lebih rendah daripada bahasa lisan.

2. Metode Pengumpulan Data

a. Metode dan Teknik Pengumpul Data 
Ada beberapa metode pengumpulan data yang lazim digunakan dalam penelitan linguistik, di antaranya adalah metode simak dan metode cakap. Dalam penelitian ini penulis menggunakan metode simak. Metode ini adalah sebuah cara yang digunakan untuk mendapatkan data dengann melakukan penyimakan terhadap penggunaan bahasa. Walaupun disebut metode simak, ianya tidak sekadar digunakan untuk menyimak penggunaan bahasa lisan melainkan bisa juga digunakan untuk mendapatkan data dari penggunaan bahasa tulis. Hal ini mengacu pada pendapat Sudaryanto yang menyatakan bahwa untuk mendapatkan data peneliti menyadap penggunaan bahasa, menyadap pembicaraan seseorang atau beberapa orang, atau menyadap penggunaan bahasa tulisan [5].

Setiap metode yang dipilih dalam penelitian diwujudkan dalam sebuah teknik atau langlah kerja yag lebih spesifik. Dalam penelitian ini teknik catat dipilih sebagai cara yang digunakan untuk menjalankan metode simak. Teknik ini dipilih sebab data yang digunakan dalam penelitian ini berupa transkrip ortografi (gambaran bunyi bahasa yg berupa tulisan atau lambang), dengan demikian peneliti akan menandai data yang telah tersedia dalam proses pencatatan. Pada teknik ini pencatatan dapat dilakukan pada kartu data yang telah disediakan. Setelah pencatatan dilakukan, peneliti melakukan klasifikasi atau pengelompokan data [5].

Data yang telah dikumpulkan diklasifikasi berdasarkan pelbagai masalah yang telah ditentukan. Dengan teknik catat, peneliti tidak perlu melakukan observasi ke lapangan sebab semua hal yang dibutuhkan (berkaitan dengan fokus penelitian) telah didapatkan melalui sumber tertulis.

b. Alat Pengumpul Data

Kartu pencatat data adalah alat yang digunakan dalam penelitian ini. Dengan kartu yang berisi tabel-tabel, peneliti akan mengisinya dengan verba yang ditemukan dalam teks kemudian menyertainya dengan keterangan-keterangan tertentu yang diperlukan.

Analisis merupakan langkah yang dilakukan jika data sudah terkumpul melalui teknik-teknik yang telah dilakukan. Analisis data adalah suatu proses mengatur urutan data, mengorganisasikannya ke dalam suatu pola, kategori, dan satu uraian dasar [9]. Analisis dalam penelitian ini menggunakan metode agih dengan teknik dasar.

Teknik analisis dasar dalam penelitian ini meliputi seleksi data, klasifikasi data, dan penyajian data yang dipaparkan sebagai berikut.

a. Seleksi Data

Seleksi data merupakan langkah pertama dalam kegiatan analisis. Seleksi (pemilihan) dilakukan agar data yang terkumpul sesuai dengan kriteria yang telah ditetapkan. Validitas dan reliabilitas data bisa dipertanggungjawabkan melalui seleksi. Secara teknis, data yang diambil hanya berupa verba dalam BMDS. Data ini terdapat dalam bentuk frasa, klausa, atau kalimat majemuk. Tahap seleksi ini diharapkan data yang ditelaah benar-benar dapat dipertanggungjawabkan kesahihan dan keterandalannya [7].

b. Klasifikasi Data
Setelah diseleksi berdasar kriteria yang ditetapkan, data selanjutnya dikasifikasi. Klasifikasi atau pengelompokkan dilakukan berdasar pada makna aspektualitas yang dimiliki oleh data. Melalui kegiatan klasifikasi akan didapatkan data berupa kata-kata, frasa-frasa, kalimat-kalimat yang mengungkapkan makna aspektualitas tertentu, misalnya inkoatif, duratif, dan iteratif [7]. Selain itu, kegiatan klasifikasi juga dilakukan untuk menentukan unsur pendukung aspektualitas.

c. Penyajian Data

Pemaparan atau penyajian data merupakan langkah terakhir dalam analisis. Data disajikan dalam bentuk deskriptif, yaitu disampaikan dengan jelas dan detail. Untuk memudahkan pemahaman, data bisa juga disajikan dalam bentuk tabel. Data yang disajikan (dilaporkan) dalam bentuk tesis harus disusun secara konsisten dan sistematis. Untuk memenuhi dua syarat tersebut, Sumarlam (2004:68) menyatakan bahwa setiap jenis aspektualitas akan diperikan ihwal cara-cara atau alat-alat pengungkapannya pada tataran frasa [7].

\section{PEMBAHASAN}

\section{PEMBAHASAN}

\section{Aspektualitas Inkoatif}

Sumarlam (2004:178) menyatakan secara aspektual frasa inkoatif menggambarkan situasi dengan penekanan pada segi awal atau mulainya suatu situasi, tanpa menghiraukan bagaimana situasi berlangsung atau berakhir [7].

a. A.6 Jadi si Ranjan iye ngayal nak jadi orang kaye yang tekannal.

b. B.4 Nak mintak nasek daan juak berani.

c. C.4 Hari itok keputusan akan saye sampaikan

d. D.12 Aku tattap nak paggi.

e. J.3 Pembantok iye pun kemudian meracik baras dan sayok-sayok untuk dijadikan makanan.

f. J.7 Lakak ngabiskan makanan iye, Raje pun nyuroh pengawalnye nyarek pembantok.

g. P.l Suatu ari be, ade nelayan yang nak diam di Perigek Piai.

h. Q.3 Dah kite kelak tok e ngambek talok panyok di Pulau Penatah.

i. $\quad$ R.2 Nong, laok usah nak diabisek, umak nak paggi kume dolok.

j. $\quad$ R.3 Mun kitak abisek kalak umak marah.

k. R.7 Pas umaknye nak makan tekajut meliat laoknye dah disek agek.

1. R.9 Kan udah umak padahkan, usah nak diabisek

Makna aspektualitas inkoatif pada data di atas didukung oleh PFA (Pemarkah Frasa Aspektualitas) nak (A.6, B.4, D.12, P.1, R.2, R.7, dan R.9), pun (J.3, J.7), dah (Q.3), dan kallak (R.3). Frasa-frasa tersebut mampu menunjukkan sebuah situasi yang menekankan pada aspek permulaan, tanpa menghiraukan apakah situasi tersebut berlangsung lama, sebentar, atau berkali-kali. Dalam penelitian ini ditemukan empat PFA dalam bahasa melayu 
Sambas yang mampu mengungkapkan aspektualitas inkoatif, yakni nak, pun, dah, dan kallak.

\section{Aspektualitas Progresif}

Berbeda dengan aspektualitas inkoatif yang menggambarkan awal/ mulainya suatu situasi, aspektualitas progresif menggambarkan situasi sedang berlangsung atau sedang dalam proses [7].

a. A.5 Sampai anaknye yang bename Ranjan udah bujang, keluarge iye maseh juak sontok.

b. A.18 Begayye perau dakat ke kapal urang tuenye meliat si Ranjan dangan bininye agek bediri meliat ke arah perau urang tuenye.

c. B.2 Tibe-tibe beduak urang sontok umak dangan anaknye yang maseh kacik dan disarok.

d. C.3 Pas sampai Putri langsong ngomong.

e. D.4 Neneknye nammukan Putri agek menangis dakkat tumpokkan batu.

f. J.6 Raje pun makannye dangan lahap.

g. P.4 Sementare undang dangan kepiting sian, die lalu merimbak batang kayu untuk dijadikan umme.

Makna aspektualitas progresif pada data di atas didukung oleh PFA (Pemarkah Frasa Aspektualitas)maseh (A.5, B.2), agek (A.18, D.4), langsong (C.3), dangan (J.6), dan lalu (P.4). Frasa-frasa yang ditunjukkan oleh PFA tersebut menunjukkan sebuah situasi yang sedang berlangsung atau sebuah keadaan yang sedang berada dalam proses. Dalam penelitian ini ditemukan lima PFA dalam bahasa Melayu Sambas yang mampu mengungkapkan aspektualitas progresif, yakni maseh, agek, langsong, dangan, dan lalu.

\section{Aspektualitas Semelfaktif}

Makna aspektualitas semelfaktif menggambarkan situasi yang berlangsung hanya satu kali dan biasanya bersifat sekejap. Situasi yang diungkapkan oleh predikat dilakukan atau dialami dengan tepat, tanpa durasi, dan terjadi pada periode yang sangat singkat [7].

a. B.1 Tibe-tibe beduak urang sontok umak dangan anaknye yang maseh kacik dan disarok.

b. B.5 Sekali ditaukan leh urang sanang-sanang.

c. C.5 Langit pun tibe-tibe gallap.

d. H.5 Tibe-tibe urang kampong.

e. H.7 Urang kampong yang tadek ngeraok tibe-tibe ngakal ketawak.

f. I.1 Kebatolan waktu ye ari tangahhan ujan panas.

Makna aspektualitas semelfaktif pada data di atas didukung oleh PFA (Pemarkah Frasa Aspektualitas) tibe-tibe (B.1, C.5, H.5, H.7), sekali (B.5), dan kebatolan (I.1). Frasafrasa yang ditunjukkan oleh PFA tersebut menunjukkan sebuah situasi yang berlangsung sekejap, tiba-tiba, dan lazimnya hanya berlaku sekali. Dalam penelitian ini ditemukan tiga PFA dalam bahasa melau Sambas yang mampu mengungkapkan aspektualitas semelfaktif, yakni tibe-tibe, sekali, dan kebatolan.

4. Aspektualitas Iteratif

Aspektualitas repetitif tidak memiliki makna berkalikali atau berulang-ulang dan aspektualitas tersebut tidak menyatakan tingkat kekerapan. Sementara itu nuansa keberkali-kalian atau keberulangan dan tingkat kekerapan diungkapkan oleh aspektualitas iteratif [7].

a. A.15 Same dangan paginye, baliknye die pun singgahsinggah juak untok njual barang dagangannye.

b. A.19 Ranjan ngan bininye capat-capat masok ke dalam kapal.

c. C.2 Pangeran dari macam-macam kerajaan pun bedatangan sigek-sigek melamar si Putri.

d. B.10 Daan boleh nak sembarangan titukok-tukok dangan barang yang ade di sie.

e. $\quad$ C.6 Killat dan lentar menyambar-nyambar.

f. D.14 Sepanjang malam die menangis lakkak iye keraok-keraok.

g. F.5 Sampai dah tige kali die meliatek dangan mate kepalak die sorang.

h. Q.6 Ning Kacong yang meliatnye ketawak tepingkalpingkal.

i. A.9 Waktu iye Ranjan udah banyak anak buah dan bekali-kali ganti kapal dan barang dagangannye pun beganti-ganti tapi belacan tatap jadi yang paling laris.

j. A.10 Waktu iye Ranjan udah banyak anak buah dan bekali-kali ganti kapal dan barang dagangannye pun beganti-ganti tapi belacan tatap jadi yang paling laris. Makna aspektualitas iteratif pada data di atas didukung oleh PFA (Pemarkah Frasa Aspektualitas) singgah-singgah (A.15), capat-capat (A.19), sigek-sigek (C.2), titukok-tukok (B.4), menyambar-nyambar (C.6), ncarek dan terus ncarek (D.13), keraok-keraok (D.14), sampai dah tige kali (F.5), ketawa tepingkal-pingkal (Q.6), bekali-kali (A,.9), dan beganti-ganti (A.10). Frasa-frasa yang ditunjukkan oleh PFA tersebut menunjukkan sebuah situasi yang berlangsung berulang-ulang, sekaligus menunjukkan tingkat kekerapan. Tidak seperti repetitif yang derajat keberulangannya hanya sekali. Dalam penelitian ini ditemukan sepuluh PFA dalam bahasa melau Sambas yang mampu mengungkapkan aspektualitas iteratif, yakni singgah-singgah, capat-capat, sigek-sigek, titukok-tukok, menyambar-nyamba, keraokkeraok, sampai dah tige kali, ketawa tepingkal-pingkal, bekali-kali, dan beganti-ganti.

\section{Aspektualitas Habituatif}

Aspektualitas habituatif ialah aspektualitas yang menggambarkan suatu situasi (keadaan, peristiwa, atau proses) yang menjadi kebiasaan [7]

a. A.l Barang jak dakat pantai keraje ayahnye ye tiap ari ke laut carek ikan.

b. A.2 Biasenye pakai jale, waktu iye alat laing jak sean.

c. D.5 Pagi iye Putri pagi ke pasar macam biase.

d. D.6 Sebanarnye nenek Putri yang biase melakukannye.

e. D.7 Die malar makse.

f. D.8 Masakan nenek malar nyaman dan makin nyaman ajak tiap ari.

g. D.9 Masakan nenek malar nyaman dan makin nyaman ajak tiap ari.

h. D.11 Die selalu kagum ngan sesuatu yang dak die tau ape namenye. 
i. F.1 Rupe nak tiap ari lalu be juak pemancing iye suke nak mancing.

j. G.4 Urang Tanjong Batu malar meliat sosok urang bassar.

k. H. 1 Kerajenye ari-ari pagi ngael ikan di laut.

1. J.8 Name saye Kassum, biasenye urang-urang manggel saye dangan sabutan Mak Kasum.

m. Q.1 Ke laut same-same ke laut, biase paggi ngambek kappah.

Makna aspektualitas habituatif pada data di atas didukung oleh PFA (Pemarkah Frasa Aspektualitas) biasenye (A.2, D.5, D.6, J.8, dan Q.1), malar (D.7, D.9, dan G.4), tiap (D.8 dan F.1), selalu (D.11), dan ari-ari (H.1). Frasa-frasa yang ditunjukkan oleh PFA tersebut menunjukkan sebuah situasi yang menjadi kebiasaan. Dalam penelitian ini ditemukan lima PFA dalam bahasa melau Sambas yang mampu mengungkapkan aspektualitas habituatif, yakni biasenye, malar, tiap, selalu, dan ari-ari.

6. Aspektualitas Kontinuatif

Makna aspektualitas kontinuatif menggambarkan situasi yang berlangsung secara terus-menerus dalam rentang waktu yang relatif lama. Keadaan yang relatif tetap dari waktu ke waktu seperti itu menggambarkan adanya situasi yang terjadi terus menerus atau kontinuitas [7]

a. A.3 Sampai anaknye yang bename Ranjan udah bujang, keluarge iye maseh juak sontok.

b. B.8 Sampai tujoh ari tujoh malam bunyi ngeriyongan dalam tarub.

c. C.1 Cantek paras Putri Mandalike tekannal dimanemane sampai ke nagarri sebarang.

d. Q.7 Sampai akhirnye Long Angah masok ke laut, Ning Kacong maseh tatap ketawak.

e. D.15 Putri tarus menangis dak beranti-beranti.

f. H.3 Dah betaun-taun ngawankannye pagi melaut.

g. D.2 Putri tatap idup di tangah kacaunye keadaan.

h. G.5 Sampai kinnitok kuboran Obos bise kite liat di Tanjong Batu.

i. Q.5 Tallok iye pun dibagikan sampai abis.

j. Q.8 Sampai akhirnye Long Angah masok ke laut, Ning Kacong maseh tatap ketawak.

k. D.13 Die ncarek dan terus ncarek tapi dak ade ape-ape. Makna aspektualitas kontinuatif pada data di atas didukung oleh PFA (Pemarkah Frasa Aspektualitas) sampai (A.3, B.8, C.1, Q.7, G.5, dan Q.5), betaun-taun (H.3), tatap (D.2), d. Frasa-frasa yang ditunjukkan oleh PFA tersebut menunjukkan sebuah situasi yang menjadi kebiasaan. Dalam penelitian ini ditemukan empat PFA dalam bahasa melayu Sambas yang mampu mengungkapkan aspektualitas habituatif, yakni sampai, betaun-taun, tatap, dan tarus.

\section{Aspektualitas Komitatif}

Makna aspektualitas komitatif ialah aspektualitas yang menggambarkan dua situasi atau lebih berlangsung dalam waktu yang bersamaan [7].

a. A.7 Sewaktu si Ranjan ikut die, barang dagangannye makin laris. b. A.8 Waktu iye Ranjan udah banyak anak buah dan bekali-kali ganti kapal dan barang dagangannye pun beganti-ganti tapi belacan tatap jadi yang paling laris.

c. A.11 Sebalom Ranjan paggi die bepadah dolok dangan umaknye.

d. A.17 Begayye perau dakat ke kapal urang tuenye meliat si Ranjan dangan bininye agek bediri meliat ke arah perau urang tuenye.

e. B.7 Die pagi ke acare nikahan ie sambel mawak kucing.

f. D.3 Putri tatap idup di tangah kacaunye keadaan.

g. G.3 Senyapat nyuroh anaknye masok ke rumah dangan nutup lawang rumahnye.

h. I.2 Kebatolan waktu ye ari tangahhan ujan panas.

i. I.4 Eh malah biak kaccik iye be keluar rumah takaan ujan panas.

j. P.3 Sementare undang dangan kepiting sian, die lalu merimbak batang kayu untuk dijadikan umme.

k. Q.2 Kisah ang pas bulan ampat balas atau ampat balas ari bulan kan tarang $e$.

1. A.14 Bininye ikut belayar sambel bedangan ke kampong halamannye.

Makna aspektualitas komitatif pada data di atas didukung oleh PFA (Pemarkah Frasa Aspektualitas)waktu (A.7 dan A.8), sebalom (A.11), begayye (A.17), sambel (A.14 dan b.7), tangah (D.3 dan I.2), dangan (G.3), takaan (I.4), sementare (P.3), dan pas (Q.2) . Frasa-frasa yang ditunjukkan oleh PFA tersebut menunjukkan sebuah situasi yang berlangsung bersamaan dengan situasi lain. Dalam penelitian ini ditemukan sembilan PFA dalam bahasa melayu Sambas yang mampu mengungkapkan aspektualitas komitatif, yakni waktu, sebalom, begayye, sambel, tangah, takaan, dangan, sementare, dan pas.

Terdapat perbedaan antara dangan pada aspektualitas progresif dengan komitatif. Dangan pada aspektualitas progresif diikuti oleh keterangan, sedangkan pada komitatif diikuti verba. Walaupun PFA-nya sama, namun posisi di dalam kalimat ikut menentukan kategori aspektualitas yang dikandungnya.

\section{Aspektualitas Duratif}

Sumarlam mengungkapkan bahwa makna aspektualitas duratif menggambarkan situasi yang berlangsung dalam kurun waktu terbatas. Konsep duratif yang lazim dianut oleh para pengamat aspektualitas adalah 'sepenggal situasi yang dibatasi oleh waktu' atau 'situasi yang berlangsung dalam waktu tertentu'[7].

a. A.13 Balom lamak ninggalkan pelabuhan Singapur, ade kapal yang dirampok leh bajak laut.

b. D.10 Die suke balamak-lamak nikmattek keindahan langit

c. G.1 Setallah berape lamak dangan kekuasaannye yang kajam, akhernye die mati dalam petamporan.

d. H.4 Ndak lamak dari paginye Long Gayot keluar.

e. P.5 Daan lamak kemudian, die pun makin rajing merimbak batang kayu.

Makna aspektualitas duratif pada data di atas didukung oleh PFA (Pemarkah Frasa Aspektualitas) lamak (A.13, D.10, G.1, H.4, dan P.5). Frasa-frasa yang ditunjukkan oleh 
PFA tersebut menunjukkan sebuah situasi yang berlangsung dalam kurun waktu tertentu. Dalam penelitian ini ditemukan satu PFA dalam bahasa melayu Sambas yang mampu mengungkapkan aspektualitas duratif, yaitu lamak.

\section{Aspektualitas Perfektif}

Aspektualitas perfektif ialah aspektualitas yang menggambarkan situasi (keadaan, peristiwa, atau proses) yang sudah terjadi, sudah selesai, atau sudah lengkap (Sumarlam, 2004:191).

a. A.4 Sampai anaknye yang bename Ranjan udah bujang, keluarge iye maseh juak sontok.

b. A.12 Sebalom Ranjan paggi die bepadah dolok dangan umaknye.

c. A.16 Berite si Ranjan jadi urang kaye dah nyabbar kemane-mane.

d. A.20 Tapi tadek waktu aku keraokek tang daan didulikannye.

e. B.3 Lakak ie urang sontok rase kanak hine lah barang daan kanak sarok.

f. B.6 Lakak ie, si sontok balk ke rumahnye.

g. D. 1 Urang tue Putri udah lamak meninggal.

h. F.2 Lakak iye die balik ke rumahnye.

i. G.2 Setallah berape lamak dangan kekuasaannye yang kajam, akhernye die mati dalam petamporan.

j. H.2 Motor aek yang dipakai tok yak udah burok.

k. I.3 Nye urang jaman gek dolok mun dah ujan panas sodah nak keluar rumah.

1. J.1 Pade jaman gek dolok iduplah seorang raje yang sangat kaye raye.

m. J.4 Lakak molah semue bahan makanan yang disiapkannye tadek ye.

n. J.5 Lakak molah semue bahan makanan yang disiapkannye tadek ye.

o. R.1 Lakkak dah masak si ummak bepasan ke anaknye yang paling tue.

p. R.4 Kakaknye dah barek tau usah nak diabisek.

q. R.5 Akhirnye umaknye pun balik ke rumah.

r. R.6 Pas umaknye nak makan tekajut meliat laoknye dah disek agek.

s. R.8 Kan udah umak padahkan, usah nak diabisek.

t. R.10 Akhirnye abislah badan umaknye ditaan batu iye.

Makna aspektualitas perfektif pada data di atas didukung oleh PFA (Pemarkah Frasa Aspektualitas) udah / dah ( R.8, R.6, R.4, H.2, I.3, D.1), dolok (A.12, J.1), akhernye (R.10), lakak (J.4, R.1), dan tadek (J.5). Frasa-frasa yang ditunjukkan oleh PFA tersebut menunjukkan sebuah situasi yang sudah berlangsung. Dalam penelitian ini ditemukan lima PFA dalam bahasa melayu Sambas yang mampu mengungkapkan aspektualitas perfektif, yaitu udah/dah, dolok, akhernye, lakak, dan tadek. Ada satu catatan utuk aspektualitas perfektif, khususnya pada pemarkah dah. Dah pada aspektualitas perfektif bisa berupa dah atau berupa udah yang bermakna sudah. Namun dah bisa juga bermakna ayo yang lazimnya dikategorikan sebagai pemarkah inkoatif.
Aspektualitas repetitif ialah aspektualitas yang menggambarkan situasi (keadaan, peristiwa,, proses) berulang.

a. B.9 Dibarek aek, tabang agek, cucokkan agek.

b. F.3 Isok ari agek die pagi mancing ke sungai iye.

c. F.4 Tatap die meliat hal yang gie agek be.

d. I.5 Si Hasan e terajjun agek sekali rupenye daan timboltimbol.

Makna aspektualitas repetitif pada data di atas didukung oleh PFA (Pemarkah Frasa Aspektualitas) agek (B.9, F.3, F.4, dan I.5). Frasa-frasa yang ditunjukkan oleh PFA tersebut menunjukkan sebuah situasi yang berlangsung berulang kali, namun tidak menunjukkan sifat kekerapan seperti iteratif.. Dalam penelitian ini ditemukan satu PFA dalam bahasa melayu Sambas yang mampu mengungkapkan aspektualitas repetitif, yaitu lamak. Sebagai catatan tambahan, agek pada PFA repetitif selalu berada di belakang verba, sedangkan agek pada PFA progresif berada sebelum verba.

\section{IV.SIMPULAN DAN SARAN}

\section{SIMPULAN}

Adapun simpulan penelitian ini adalah sebagai berikut.

1. Terdapat sepuluh jenis aspektualitas yang ditemukan dalam BMDS, yaitu inkoatif, progresif, semelfaktif, iteratif, habituatif, kontinuatif, komitatif, duratif, perfektif, dan repetitif.

2. Terdapat empat pemarkah frasa aspektualitas inkoatif, yaitu nak, pun, dah, dan kallak.

3. Terdapat lima pemarkah frasa aspektualitas progresif, yaitu maseh, agek, langsong, dangan, dan lalu.

4. Terdapat tiga pemarkah frasa aspektualitas semelfaktif, yaitu tibe-tibe, sekali, dan kebatolan.

5. Terdapat sepuluh pemarkah frasa aspektualitas iteratif, yaitu singgah-singgah, capat-capat, sigek-sigek, titukok-tukok, menyambar-nyambar, keraok-keraok, tige kali, tepingkal-pingkal, bekali-kali, dan begantiganti.

6. Terdapat lima pemarkah frasa aspektualitas habituatif, yaitu biasenye, malar, tiap, selalu, dan ari-ari.

7. Terdapat empat pemarkah frasa aspektualitas kontinuatif, yaitu sampai, betaun-taun, tatap, dan tarus.

8. Terdapat sembilan pemarkah frasa aspektualitas komitatif, yaitu waktu, sebalom, begayye, sambel, tangah, takaan, dangan, sementare, dan pas.

9. Terdapat satu pemarkah frasa aspektualitas duratif, yaitu lamak.

10. Terdapat lima pemarkah frasa aspektualitas perfektif, yaitu udah, dolok, akhernye, lakak, dan kalak.

11. Terdapat satu pemarkah frasa aspektualitas repetitif, yaitu agek.

10. Aspektualitas Repetitif 
Berdasarkan hasil simpulan yang telah dikemukakan, ada beberapa saran yang bisa dilakukan sebagai tindak lanjut penelitian ini. Di antaranya adalah:

1. Penutur asli BMDS mesti menggunakan bahasa Melayu dengan tepat. Minimal mampu memilih penggunaan pemarkah waktu ketika berkomunikasi.

2. Penelitian ini hanya membahas satu aspek sintaksis, yaitu frasa. Penelitian untuk aspek yang lain masih terbuka lebar sehingga masih bisa dilakukan pada aspek klausa dan kalimat.

\section{DAFTAR PUSTAKA}

[1] Astri, Nanda Dwi. 2014. Aspektualitas dalam Bahasa Jawa di Desa Bandar Tengah Kecamatan Bandar Khalipah. Jurnal Telangkai Bahasa dan Sastra ed.Juli 2014 FIB Universitas Sumatera Utara.

[2] Djajasudarma, Fatimah. 2009. Metoe Linguistik: Ancangan Metode Penelitian dan Kajian. Bandung: Refika Aditama.

[3] Mahsun, M.S.2007. Metode Penelitian Bahasa: Tahapan Strategi, Metode, dan Tekniknya. Jakarta: PT Raja Grafindo Persada.

[4] Moleong, Lexy. 2009. Metode Penelitian Kualitatif. Bandung: Remaja Rosdakarya.

[5] Muhammad. 2011. Metode Penelitian Bahasa. Jogjakarta: Ar Ruzz Media.

[6] Nawawi, Hadari. 2015. Metode Penelitian Bidang Sosial. Yogyakarta: UGM Press.

[7] Sumarlam. 2004. Aspektualitas Bahasa Jawa: Kajian Morfologi dan Sintaksis. Surakarta: Pustaka Cakra.

[8] Tadjuddin, Mohammad. 2005. Aspektualitas dalam Kajian Linguistik. Bandung: PT Alumni.

[9] Patton, Michael Quinn. 1987. Qualitative Education Methods, Beverly Hills. Sage: Publication. 